\title{
Family Firms and Tax Aggressiveness in Brazil
}

\author{
Antonio Lopo Martinez ${ }^{1} \&$ Giliard Creton Ramalho ${ }^{2}$ \\ ${ }^{1}$ Fucape Business School, Brazil \\ ${ }^{2}$ Vale S. A., Brazil \\ Correspondence: Antonio Lopo Martinez, Fucape Business School, Av. Fernando Ferrari, 1358. Boa Vista, \\ Vitória-ES CEP 29075-505, Brazil. Tel: 55-27-4009-4444. E-mail: lopo@fucape.br
}

Received: December 23, 2013

Accepted: January 13, 2014

Online Published: February 24, 2014

doi:10.5539/ibr.v7n3p129

URL: http://dx.doi.org/10.5539/ibr.v7n3p129

\begin{abstract}
This article investigates whether family firms are more aggressive in terms of tax planning than non-family firms in Brazil, based on a sample of firms listed on the BMF\&Bovespa from 2001 to 2012. Chen, Chen, Cheng, \& Shevlin (2010) define tax aggressiveness as management to reduce taxable income through tax planning activities. Of the sample of companies, $23 \%$ are considered to be family firms. We found a significant relationship between classification as a family firm and tax aggressiveness, based on two metrics. The first, effective tax rate (ETR), captures the actual taxes paid in relation to pre-tax earnings, while the second, book-tax differences (BTD), reflects the differences between accounting income and taxable income. The family firms in the sample were more tax aggressive than the non-family firms. For the variable BTD, family firms presented a positive sign, indicating a tendency for higher BTD. In turn, ETR had a negative sign, identifying a tendency for family firms to pay lower taxes.
\end{abstract}

Keywords: effective tax rate, book-tax differences, family firms, tax aggressiveness

\section{Introducation}

Taxes account for a significant cost to businesses and their shareholders, so actions to reduce the tax burden are desirable. However, there are potential costs related to strategies to minimize taxes, such as implementation and transaction costs, possible penalties imposed by the tax authorities and reputation risks, that must be pondered (Desai \& Dharmapala, 2006; Hanlon \& Slemrod, 2009).

According to Chen, Chen, Cheng and Shevlin (2010), tax aggressiveness is the "downward management of taxable income through tax planning activities." These activities encompass both activities considered legal and illegal (as well as those in the inevitable gray area between the two). Earlier studies by Chen \& Chu (2005), Crocker \& Slemrod (2005) and Desai \& Dharmapala (2006) established the bases for the relationship between tax aggressiveness and agency questions. Because managers have privileged information on the extent of legally permissible reductions of income taxes, they can also increase the size of tax deductions through illegal tax evasion measures. The incentives for managers to stretch the limits of tax rules depend on the nature of their remuneration mechanisms and the potential personal penalties for getting caught.

Chen et al. (2010) studied the implications of tax aggressiveness and the specific agency conflict that exists in family firms, defined as those in which members of the founding family continue to hold senior management positions, seats on the board of directors or relevant stakes in the controlling block. In these companies, there should be a greater agency conflict between majority and minority shareholders and a lesser one between owners and managers in comparison with non-family firms.

The degree of tax aggressiveness will depend on the characteristics of the owners of family firms and the managers of non-family firms with respect to the costs and benefits of aggressive tax planning policies. However, the relationship between the characteristic of being a family firm and tax aggressiveness cannot be clearly identified a priori. Due to the greater block holdings and longer investment horizons, the owners of family firms need to be more concerned with the potential penalties and the reduction of the share price that can be caused by overly aggressive tax planning. On the other hand, they also tend to reap greater economic benefits from lowering the firm's tax liability than is the case of managers of non-family firms. This situation results in the need for empirical investigation of the relative propensity of family firms to engage in aggressive tax planning. 
There is a gap in the Brazilian accounting literature about the existence of a relationship between family ownership and tax aggressiveness, prompting us to pose the following research question: What is the relationship between tax aggressiveness and family ownership of companies?

More precisely, this article aims to understand the relationship between family control and tax aggressiveness of firms listed on the São Paulo Mercantile, Futures and Stock Exchange (BM\&FBovespa), through the following steps: i) analyzing the extant literature on the matter; ii) gathering economic and financial data on the companies in the sample; iii) applying the methods to measure tax aggressiveness indicated in the literature to the data collected; iv) analyzing the data on the level of tax aggressiveness and relating it with the ownership characteristics of firms, divided between family and non-family firms; and v) reflecting on the results obtained in the context of the theme.

We believe this study makes two significant contributions to the accounting literature in Brazil. First, the results provide important support for a better understanding of the impact of firms' ownership structures, demonstrating whether agency conflicts directly affect firms' tax aggressiveness. Second, the results show that the non-fiscal costs resulting from agency conflicts can have a significant impact on the tax planning activities of Brazilian companies.

\section{Theoretical Framework}

This study is based on previous articles, such as Chen \& Chu (2005), Crocker \& Slemrod (2005) and Desai \& Dharmapala (2006), that have examine the issue of corporate tax aggressiveness and evasion considering agency questions. These are based on theories of the cost-benefit relations that are considered by managers in their tax planning, with the benefit of aggressiveness defined as the tax saving attained and the costs classified as those for implementation (e.g., time and effort, transaction costs) and the potential political and reputational costs (Scholes et al., 2005; Hanlon \& Slemrod, 2009; Chen et al., 2010). Therefore, from the perspective of agency theory and tax aggressiveness, the tax management of firms takes into consideration the potential costs versus benefits.

\subsection{Tax Aggressiveness}

Tax aggressiveness has been examined by a number of researchers (Dunbar, Higgins, Phillips, \& Plesko, 2010). As mentioned, Chen et al. (2010) define tax aggressiveness as the use of tax planning actions for downward management of taxable income. In turn, Frischmann, Shevlin and Wilson (2008) define it as engaging in significant tax positions with relatively weak supporting facts. Another definition is given by Lisowsky, Robinson, Schmidt (2010), as a set of tax avoidance activities falling along a continuum from legitimate tax planning to abusive use of offshore tax shelters.

Dunbar et al. (2010) present a review of the metrics used to measure tax aggressiveness in the literature. According to them, of the tax aggressiveness metrics generally used, four are variants of the effective tax rate (ETR), two are based only on book-tax differences (BTDs) and three others are based on estimating econometric models that capture the abnormal tax planning behaviors that can be a reflection of tax aggressiveness.

Hanlon \& Slemrod (2009), analyzing the relation between stock prices and news of firms' tax aggressiveness (involvement in tax shelters), find that on average the stock price declines when there is news about involvement in tax shelters, but the reaction is small in relation to news about other types of wrongdoing.

According to Chen et al. (2010), firms determine their level of tax aggressiveness based on a tradeoff of the marginal benefits and costs of managing taxes. The marginal benefits basically consist of the tax savings while the marginal costs include those for implementation (time and effort, transaction costs), the potential penalties that can be applied by the tax authorities, along with the possible reputation cost and decline in stock price in reaction to news of tax misdeeds.

\subsection{Agency Theory and Tax Aggressiveness}

Various studies have empirically tested aspects of tax aggressiveness associated with questions involving agency conflict. Agency conflict is generally defined in line with the concept presented by Jensen \& Meckling (1976), according to which the function that maximizes the utility of managers (agents) does not necessarily maximize the utility of stockholders (principals). Therefore, it is possible for the decisions made by agents to be different than those considered optimal by the principals, causing conflicts.

Lanis \& Richardson (2011) examine the effect of the composition of the board of directors and tax aggressiveness and find that the inclusion of a larger number of independent directors reduces the probability of aggressive tax planning. Crocker \& Slemrod (2005) study corporate tax evasion in the context of contractual 
relations between the shareholders and the chief financial officer, who is assumed to have private information about the permissible ways to reduce the company's taxable income. The authors use modeling to formulate an optimal incentive compensation contract. They conclude that the penalties imposed on the CFO directly are more effective to reduce tax evasion than are those imposed on the stockholders.

In turn, Chen et al. (2010) study the relationship between tax aggressiveness and agency conflicts present in family firms and non-family firms. The reason to deal with these two types of companies separately is that, according to the authors, the presence of members of the founding family in the ownership structure implies a greater potential for conflict between majority and minority shareholders and a lesser one between owners and managers in comparison to non-family firms. This difference can impact the costs and benefits of implementing more or less aggressive tax policies.

\subsection{Family Firms and Tax Aggressiveness}

According to Bagnoli, Liu \& Watts (2011), family firms are surprisingly common. Indeed, in Europe and Asia family firms are at least as common as non-family firms (La Porta, Lopez-de-Silanes, \& Shleifer, 1999). According to Zborowski, Leal \& Bortolon (2011), the presence of family firms in Brazil is still very relevant. They studied the presence of founding family members in the ownership, management and control structure of firms listed on the BM\&FBovespa and compared the control, governance and financial performance of these firms against non-family firms. According to their definition, a family firm is one where a founding family member is present among the owners (at least $5 \%$ of the shares), holds an executive position (board of directors or executive board) or where one or more family members exercise outright control. By these criteria, which we followed as well, $25 \%$ of our sample of listed Brazilian companies can be classified as family firms. Chen et al. (2010) have a similar framework, defining family firms as those "where members of the founding family continue to hold positions in top management, are on the board, or are blockholders of the company." They argue that the presence of the founding family leads to a different ownership structure than that in other companies.

According to Steijvers \& Niskanen (2011), family firms are considered to have low agency costs. For Chen et al. (2010) in comparison with the managers of non-family firms, the owners of family firms have larger equity stakes, longer investment horizons and are more concerned over reputation. This leads to stronger incentive for alignment between managers and owners, and hence lesser agency conflict in this respect. On the other hand, though, it implies greater agency conflict between minority and majority shareholders.

The typically larger equity holding of family owners provides greater gains from the savings obtained through tax avoidance actions, including by transactions with related parties (Chen et al., 2010). Therefore, family firms should have higher incentives for tax aggressiveness. However, the costs are also potentially higher for family owners, because of the commensurately greater loss from the decline of the stock price caused by negative perceptions of tax aggressiveness and their less diversified wealth (Chen et al., 2010).

As can be seen from this literature review, there is a gap in the Brazilian accounting literature regarding the existence of a relationship between family ownership and tax aggressiveness. To fill this gap, we test the following hypothesis:

\section{H1: Brazilian family firms are more tax aggressive than non-family firms.}

\section{Methodology}

The methodology used to test this hypothesis is adapted from the work of Chen et al. (2010). We employ a sample of firms listed on the BM\&FBovespa and apply linear regression to panel data, with tax aggressiveness measured by the effective tax rate (ETR) (Note 1) and the book-tax difference (BTD), for triangulation with the main control variables.

Below is a summary of the main aspects of the variables used in the regression equations:

\subsection{Classification of Family Firms}

To identify the family firms, we searched for information at the websites of each company or by sending an e-mail message through the investor relations channel. The criterion for classification was the presence of a member of the founding family in at least one of the three level - control, ownership of management. To identify family members, we compared the full name of the founders of each company with the surname of the main shareholders and managers. We considered control to exist when family members hold the largest stake in the common shares, while for ownership we considered a threshold at least $5 \%$ of the common shares held by family members. The presence of family members in executive positions was verified by consulting the information contained in the annual reports, to see if any family members sit on the board of directors. Companies with 
shareholders consisting exclusively of legal entities were classified as non-family. These parameters are the same as those used by Zborowski et al. (2011).

Table 1. Criterion for classification as a family firm

\begin{tabular}{cc}
\hline Variables & Description \\
\hline Control & Largest percentage of common shares held by family members \\
Ownership & A family member holds at least $5 \%$ of the common shares. \\
Management & A family member sits on the board of directors. \\
\hline
\end{tabular}

\subsection{Measures of Tax Aggressiveness-Dependent Variables}

We used two tax aggressiveness measures, as presented in Table 2:

Table 2. Tax aggressiveness measures

\begin{tabular}{ccc}
\hline Measure & Calculation & Description \\
\hline ETR - effective tax rate & Total income tax expense / earnings before & income tax \\
BTD - book-tax difference & (earnings before income tax - taxable \\
income (Note 3)) / total assets & $\begin{array}{c}\text { Reflects the actual income tax rate in } \\
\text { relation to pretax profit (Note 2) }\end{array}$ \\
& & $\begin{array}{c}\text { Reflects the difference between gook } \\
\text { income and taxable income, scaled by total } \\
\text { assets. }\end{array}$ \\
\hline
\end{tabular}

\subsection{Control Variables}

The control variables are presented in Table 3 below:

Table 3. Control variables

\begin{tabular}{|c|c|}
\hline Measure & Calculation \\
\hline ROA - return on assets & Operating profit of firm $\mathrm{i}$ in year $\mathrm{t}$ divided by total assets in the previous year. \\
\hline LEV - leverage & $\begin{array}{l}\text { Leverage of firm } \mathrm{i} \text { in year } \mathrm{t} \text {, measure as the long-term debt divided by total assets in the } \\
\text { previous year. }\end{array}$ \\
\hline PPE - plant, property and equipment & $\begin{array}{l}\text { Natural logarithm of property, plant and equipment of firm i in year } t \text {, divided by total assets } \\
\text { in the previous year. }\end{array}$ \\
\hline SIZE & Natural logarithm of the market value of firm $i$ at the start of year $t$. \\
\hline $\mathrm{MB}$ - market to book & Market value of firm $i$ at the start of year $t$ divided by its equity value at that time. \\
\hline
\end{tabular}

The regression equation employed was the following:

$$
\text { Taxaggr }_{i, t}=\alpha_{0}+\beta_{1} \text { Fam }_{i, t}+\beta_{j} \text { control variables } i, t+\varepsilon_{i, t}
$$

The expectation is that the tests of significance for the variable Fam $_{i, t}$ as well as the sign of the coefficient, will demonstrate that family firms present differences in tax aggressiveness in relation to non-family firms.

\section{Results}

\subsection{Database}

The samples used were obtained from the companies listed on the BM\&FBovespa between 2001 and 2012, obtained from the Economatica database. From this group, we excluded firms with insufficient information to classify them as family or non-family firms and those that had negative equity in any year, leaving a total of 441 firms, of them 94 family firms. Therefore, the total number of observations was 2076, with 539 observations 
applying to family firms.

Table 4 below presents the descriptive statistics of the variables for the sample of companies:

Table 4. Descriptive statistics of the sample

\begin{tabular}{|c|c|c|c|c|c|}
\hline Variable & No. of Observations & Mean & Standard Deviation & Min & $\operatorname{Max}$ \\
\hline ROA & 2076 & 6.540 & 8.125 & -31.000 & 86.000 \\
\hline LEV & 2034 & 23.827 & 16.650 & 0.000 & 80.000 \\
\hline SIZE & 2076 & 14.469 & 1.738 & 9.170 & 20.850 \\
\hline PPE & 2041 & 12.526 & 2.467 & 3.000 & 19.850 \\
\hline MB & 2076 & 1.042 & 1.334 & 0.004 & 10.000 \\
\hline BTD & 2076 & 1.5 & 5.4 & -38.6 & 40.3 \\
\hline ETR & 2076 & 27.4 & 15.3 & 0.000 & 97.8 \\
\hline Family & 2076 & 0.26 & 43.9 & 0.000 & 1.000 \\
\hline
\end{tabular}

The correlations between the variables are presented in Table 5 below. Note the negative correlation of the variable Family with the majority of other variables. Family firms pay a lower effective tax rate (ETR) than non-family firms, while for the variable BTD the correlation is positive, indicating that family firms tend to have a greater gap between book income and taxable income. Based on these two metrics, family firms are more tax aggressive than non-family firms.

Table 5. Correlation between the variables

\begin{tabular}{|c|c|c|c|c|c|c|c|c|}
\hline & ROA & LEV & SIZE & PPE & MB & BTD & ETR & Family \\
\hline ROA & 1 & & & & & & & \\
\hline LEV & -0.2286 & 1 & & & & & & \\
\hline SIZE & 0.0084 & 0.2421 & 1 & & & & & \\
\hline PPE & -0.0013 & 0.3006 & 0.7048 & 1 & & & & \\
\hline MB & -0.2258 & -0.0838 & -0.1962 & -0.155 & 1 & & & \\
\hline BTD & 0.7016 & -0.1474 & 0.0785 & -0.0082 & -0.1282 & 1 & & \\
\hline ETR & -0.0654 & 0.0097 & -0.0078 & 0.0781 & 0.0201 & -0.3182 & 1 & \\
\hline Family & 0.0383 & 0.0305 & -0.0598 & -0.0841 & -0.0291 & 0.0648 & -0.0991 & 1 \\
\hline
\end{tabular}

\subsection{Comparison between Family and Non-Family Firms}

To make the analysis more robust, we applied Student's t-test to analyze the equality of the means between the variables of the family and non-family firms. The results are reported in Table 6 . There were no significant differences with respect to the variables ROA, LEV and MB for the family firms in relation to the non-family firms, at the $90 \%$ confidence level. However, there were significant differences at this confidence level for BTD and ETR.

Table 6. Test of equality of the means (t-test): family firms vs. non-family firms

\begin{tabular}{lcc}
\hline & T-statistic T & $p$-value \\
\hline ROA & -1.025825958 & 0.3050686 \\
LEV & -1.071618771 & 0.2839923 \\
SIZE & 1.748651073 & 0.0804688 \\
\hline
\end{tabular}




\begin{tabular}{lll}
\hline PPE & 3.044866245 & 0.0023514 \\
MB & 1.108589467 & 0.2677093 \\
BTD & -1.823097541 & 0.0684028 \\
ETR & 3.416977274 & 0.0006429 \\
\hline
\end{tabular}

As a further test of the hypothesis of a relationship between being a family firm and tax aggressiveness, we performed regression analysis, with the dummy variable Family, with value 1 for family firms and 0 for non-family firms, and BTD and ETR as the dependent variables. If the Family variable is statistically significant, this will indicate that the characteristic of being a family firm has a relationship with tax aggressiveness. A positive coefficient when using the dependent variable ETR will show that family firms are less aggressive because it will indicate they pay a higher effective tax rate in relation to the non-family firms, while a negative coefficient with the same dependent variable will show they are less fiscally aggressive. For the dependent variable BTD, a positive sign will indicate that family firms are more aggressive, because there is larger difference between their book income and taxable income, with the opposite applying to a negative sign.

Table 7. Regression—Dependent variable: ETR

\begin{tabular}{ccccccc}
\hline ETR & Coeff. & Std. Err. & $\mathrm{t}$ & $\mathrm{P}>\mathrm{t}$ & \multicolumn{2}{c}{ Confidence Interval (95\%) } \\
\hline ROA & -0.0012353 & .0004447 & -2.78 & 0.006 & -0.0021074 & -0.0004 \\
LEV & -0.0002039 & .0002237 & -0.91 & 0.362 & -0.0006426 & 0.0002 \\
SIZE & -0.0111943 & .0028824 & -3.88 & 0.000 & -0.0168471 & -0.0055 \\
PPE & 0.0102423 & .001994 & 5.14 & 0.000 & 0.0063318 & 0.0142 \\
MB & 0.0002722 & .0027167 & 0.10 & 0.920 & -0.0050558 & 0.0056 \\
Family & -0.0312755 & .0077859 & -4.02 & 0.000 & -0.0465449 & -0.0160 \\
_Constant & 0.3294565 & .0315241 & 10.45 & 0.000 & 0.2676328 & 0.3913 \\
\hline Number of obs & 2001 & & & & & \\
F( 6, 1994) & 9.11 & & & & & \\
Prob $>$ F & 0 & & & & & \\
R-squared & 0.0267 & & & & & \\
Adj R-squared & 0.0237 & & & & & \\
Root MSE & 0.1524 & & & & & \\
\hline
\end{tabular}

Table 7 shows that the Family variable is significant at the 95\% level, indicating that being a family firm has a relationship with tax aggressiveness. The negative sign of the coefficient shows family firms tend to practice more aggressive tax planning than non-family firms according to the ETR indicator.

Table 8. Regression—dependent variable: BTD

\begin{tabular}{|c|c|c|c|c|c|c|}
\hline BTD & Coeff. & Std. Err. & $\mathrm{T}$ & $\mathrm{P}>\mathrm{t}$ & \multicolumn{2}{|c|}{ (95\%) Confidence Interval } \\
\hline ROA & 0.0046755 & .0001096 & 42.67 & 0.000 & 0.0044606 & 0.00489 \\
\hline LEV & 0.0000442 & .0000551 & 0.80 & 0.423 & -0.0000639 & 0.000152 \\
\hline SIZE & 0.0051518 & .0007102 & 7.25 & 0.000 & 0.0037589 & 0.006545 \\
\hline PPE & -0.0024926 & .0004913 & -5.07 & 0.000 & -0.0034561 & -0.00153 \\
\hline MB & 0.0019854 & .0006694 & 2.97 & 0.003 & 0.0006726 & 0.003298 \\
\hline Family & 0.0046732 & .0019185 & 2.44 & 0.015 & 0.0009108 & 0.008436 \\
\hline Constant & -0.064088 & .0077675 & -8.25 & 0.000 & -0.0793213 & -0.04885 \\
\hline
\end{tabular}




$\begin{array}{cc}\text { Number of obs } & 2001 \\ \text { F(6, 1994) } & 343.14 \\ \text { Prob }>\text { F } & 0.000 \\ \text { R-squared } & 0.508 \\ \text { Adj R-squared } & 0.5065 \\ \text { Root MSE } & 0.03755\end{array}$

Table 8 shows the same relationship between family firms and tax aggressiveness when using BTD as the dependent variable, again at $95 \%$ significance. The positive sign shows that family firms tend to have larger positive differences between book income and taxable income than to non-family firms.

\section{Conclusion}

The objective of this study was to verify if there is a relationship between the characteristic of being a family firm and the level of tax aggressiveness of companies listed on the BM\&FBovespa. We used two metrics of tax aggressiveness. The first, ETR, captures the effective tax rate paid in relation to earnings before income taxes, while the second, BTD, reflects the difference between accounting income and taxable income, with a larger difference assumed to indicate more aggressive tax planning.

We used regression analysis to test the hypothesis of the existence of a relationship between being a family firm and tax aggressiveness. According to the results for the ETR metric, Brazilian family firms are more tax aggressive than their counterpart non-family firms, because in relation to the dummy variable for family firms it was statistically significant at the $95 \%$ level and presented a negative sign, indicating that family firms on average pay a lower effective tax rate than do non-family firms. In turn, the coefficient of the BTD metric was positive and statistically significant at the same level, showing the existence of a larger gap between book income and taxable income for family firms, supplying further evidence that they tend to be more tax aggressive.

This result is opposite that found by Chen et al. (2010) for American firms. We can suggest two possible explanations for this. First, in Brazil taking an aggressive stance on taxes is not viewed by the public in such a negative light as in the United States, given the much higher rate of tax avoidance/evasion by companies and people in general, particularly because of the large informal economy, which is conducive to underreporting of income. This at least allays fear of the negative effects on stock prices of news about aggressive tax planning. The other possible explanation is the fact that many other taxes at the federal, state and municipal level that weigh heavily on firms' results are not captured by the two measures of tax aggressiveness applied here (ETR and BTD).

As avenues for future research, we suggest an investigation of the relationship of the BTD metric with family ownership, adding other control variables and using other statistical models, to make the analysis of the association of this metric more robust in relation to firms' characteristics, or investigating its relationship with other characteristics of the ownership structure, such as concentrated versus dispersed shareholding or the ratio between common and preferred shares.

\section{References}

Amy, D., Danielle, M. H., John, D. P., \& George, A. P. (2010). Proceedings of the Annual Conference on Taxation.

Bagnoli, M., Liu, H., \& Watts, S. (2011). Family Firms, Debtholder-Stockholder Agency Costs and the Use of Covenants in Private Debt. Annals of Finance, 7(4), 477-509. http://dx.doi.org/10.1007/s10436-009-0127-9

Chen, K.-P., \& Chu, C. (2005). Internal control vs. external manipulation: A model of corporate income tax evasion. The Rand Journal of Economics, 36, 151-164.

Chen, S., Chen, X., Cheng, Q., \& Shevlin, T. (2010). Are family firms more tax aggressive than non-family firms? Journal of Financial Economics, 95, 41-61. http://dx.doi.org/10.1016/j.jfineco.2009.02.003

Crocker, K., \& Slemrod, J. (2005). Corporate tax evasion with agency costs. Journal of Public Economics, 89 , 1479-1505. http://dx.doi.org/10.1016/j.jpubeco.2004.08.003

Desai, M., \& Dharmapala, D. (2006). Corporate tax avoidance and high-powered incentives. Journal of Financial Economics, 79, 145-179. http://dx.doi.org/10.1016/j.jfineco.2005.02.002 
Frischmann, P. J., Shevlin, T., \& Wilson, R. (2008). Economic consequences of increasing the conformity in accounting for uncertain tax benefits. Journal of Accounting \& Economics, 46(2/3), 261-278. http://dx.doi.org/10.1016/j.jacceco.2008.08.002

Hanlon, M., \& Heitzman, S. (2010). A review of tax research. Journal of Accounting and Economics, $127-178$. http://dx.doi.org/10.1016/j.jacceco.2010.09.002

Hanlon, M., \& Slemrod, J. (2009). What does tax aggressiveness signal? Evidence from stock price reactions to news about tax shelter involvement. Journal of Public Economics, 93, 126-141. http://dx.doi.org/10.1016/j.jpubeco.2008.09.004

Jensen, M. C., \& Heckling, W. H. (1976). Theory of the firm: managerial behavior, agency costs and ownership structure. Journal of Financial Economics, 3, 305-360. http://dx.doi.org/10.1016/0304-405X(76)90026-X

Lanis, R., \& Richardson, G. (2011). The effect of board of director composition on corporate tax aggressiveness. Journal of Accounting and Public Policy, 30, 50-70. http://dx.doi.org/10.1016/j.jaccpubpol.2010.09.003

Laporta, R., Lopez-de-Silanes, F., \& Shleifer, A. (1999). Corporate ownership around the world. Journal of Finance, 54, 471-517. http://dx.doi.org/10.1111/0022-1082.00115

Lisowsky, P., Robinson, L., \& Schmidt, A. (2010). An Examination of FIN 48: Tax Shelters, Auditor Independence, and Corporate governance. Working paper, University of Illinois at Urbana-Champaign, Tuck School of Business at Dartmouth, and Columbia University.

Scholes, M. S., Wolfson, M. A., Erickson, M., Maydew, E. L., \& Shelvin, T. (2005). Taxes and Business Strategy: A Planning Approach (3rd ed.). Upper Saddle River, NJ: Prentice-Hall.

Steijvers, T., \& Niskanen, M. (2011). Proceedings of the European Conference on Management. Leadership \& Governance.

Zborowski, B. I., Leal, P. R., \& Bortolon, M. P. (2011). Empresas Familyes no Índice Ibovespa. Relatórios COPPEAD.

\section{Notes}

Note 1. Income is only taxed at the federal level in Brazil, on a worldwide basis (subject to compensation against foreign taxes in the case of subsidiaries located in companies with which Brazil maintains treaties to prevent double taxation of income).

Note 2. We did not consider other taxes, such as municipal service tax, state value-added tax and federal tax on manufactured products, among others. These vary greatly depending on the nature of the company's business activities.

Note 3. Since the exact amount of taxable income is not contained in the financial statements, we estimated it by dividing the amount of income tax and social contribution on profit (the latter being a separate levy whose revenue is reserved for specific uses rather than going into the general fund, but that falls on the same base as corporate income tax) by the combined rate of these two levies, $34 \%$.

\section{Copyrights}

Copyright for this article is retained by the author(s), with first publication rights granted to the journal.

This is an open-access article distributed under the terms and conditions of the Creative Commons Attribution license (http://creativecommons.org/licenses/by/3.0/). 